\title{
Peningkatan Kemampuan Representasi Matematis Melalui Model Problem-Based Learning Pada Siswa SMP/MTs
}

\author{
Susanti ${ }^{1}$, M. Duskri ${ }^{2}$ Melya Rahmi ${ }^{3}$ \\ 1,2Program Studi Pendidikan Matematika,Universitas Islam Negeri Ar-Raniry Banda Aceh, Indonesia \\ email: susanti@ar-raniry.ac.id,m.duskri@ar-raniry.ac.id \\ ${ }^{3}$ Mahasiswa Prodi Pendidikan Matematika, Universitas Islam Negeri Ar-Raniry Banda Aceh, Indonesia \\ email: melyamr.mr@gmail.com
}

\begin{abstract}
Abstrak. Penelitian ini bertujuan untuk mengetahui peningkatan kemampuan representasi matematis siswa setelah diterapkan Model Problem Based Learning (PBL) pada siswa SMP/MTs, dan peningkatan kemampuan representasi matematis siswa SMP/MTs yang diterapkan Model PBL dan yang diterapkan Pembelajaran Konvensional. Metode penelitian yang digunakan adalah penelitian quasi eksperimen dengan desain Control Group Pretest-Posttest Design. Sampel penelitian ini terdiri 27 siswa kelas eksperimen dan 28 kelas kontrol. Sampel dalam penelitian ini diambil secara simple random sampling. Pengumpulan data digunakan dengan menggunakan lembar tes kemampuan representasi matematis. Teknik analisis data yang digunakan yaitu uji N-Gain, uji paired sample ttest, dan uji-t independent. Dari hasil penelitian diperoleh: (1) Penerapan Model PBL dapat meningkatkan kemampuan representasi matematis dengan nilai rata-rata $\mathrm{N}$-Gain nya 0.43 yang tergolong "sedang", dan berdasarkan uji paired sampel t test diperoleh thitung $>t_{\text {tabel }}$ atau $21.11>$ 1.71 sehingga kemampuan representasi matematis meningkat secara signifikan (2) Berdasarkan uji-t independent, diperoleh $t_{\text {hitung }}>t_{\text {tabel }}$ atau $7.00>1.675$ dapat disimpulkan bahwa kemampuan representasi matematis siswa yang dibelajarkan model PBL lebih baik dari kemampuan representasi matematis siswa yang dibelajarkan dengan pembelajaran konvensional.
\end{abstract}

Kata Kunci: Model PBL, Kemampuan Representasi Matematis

\begin{abstract}
This study aims to determine the improvement of students' mathematical representation skills after the application of the PBL model in SMP / MTs students, and the improvement of the mathematical representation skills of SMP / MTs students applied by the PBL model and those applied in conventional Learning. The research method used was quasi-experimental research with Pretest-Posttest Design Group Control. The study sample consisted of 27 experimental class students and 28 control classes. The sample in this study was taken by simple random sampling. Data collection is used by using mathematical representation skills test sheets. Data analysis techniques used are N-Gain test, paired sample t-test, and independent t-test. From the results of the study, we obtained: (1) Application of the PBL Model can improve the skills of mathematical representation with the average value of $\mathrm{N}$-Gain 0.43 which is classified as "moderate", and based on paired sample $t$ test obtained $t_{\text {count }}>t_{\text {table }}$ or $21.11>1.71$ so that the ability of mathematical representation increases significantly (2) Based on the independent $t$-test, obtained $t_{\text {count }}>t_{\text {table }}$ or $7.00>1.675$ it can be concluded that the mathematical representation skilss ability of students who are taught the PBL model is better than the skills of mathematical representation of students taught with conventional learning.
\end{abstract}

Keywords: PBL Model, Mathematical Representation Ability

\section{PENDAHULUAN}

Salah satu kemampuan yang dituntut dalam pembelajaran matematika adalah kemampuan representasi matematis. Menurut National Council of Teacher Mathematics (NCTM) representasi 
merupakan translasi suatu masalah atau ide dalam bentuk baru, termasuk di dalamnya dari gambar atau model fisik ke dalam bentuk simbol, kata-kata atau kalimat (National Council of Teachers of Mathematics, 2000, hlm. 26). Pentingnya representasi tampak pada tujuan pemecahan masalah dan komunikasi matematika, karena untuk menyelesaikan masalah matematis, diperlukan kemampuan untuk membuat model matematika dan menafsirkan solusinya yang merupakan indikator representasi.

Beberapa penelitian yang telah dilakukan untuk meningkatkan kemampuan representasi matematis (Bagus, 2018; Nurjani -, 2016; Sari \& Sari, 2019; Susilawati, Chandra, \& Abadyo, 2019). Pada Penelitian Muhammad Farhan peneliti hanya melihat peningkatan secara keseluruhan tanpa memperhatikan peningkatan dari setiap siswa (Farhan \& Retnawati, 2014, hlm. 234). Pada penelitian Fitri Sabrina peneliti tidak menggunakan pedoman penskoran terhadap indikator kemampuan representasi dan data yang diperoleh merupakan data berskala interval dan tidak mendeskripsikan hasil per indikator (Sabrina, 2015).

Salah satu alternatif yang dapat digunakan untuk meningkatkan kemampuan representasi matematis yaitu penerapan model PBL. Beberapa peneltian tentang PBL telah digunakan untuk meningkatkan kemampuan pemecahan masalah matematis (Reski, Hutapea, \& Saragih, 2019), kemapuan literasi (Hidayat, Roza, \& Murni, 2019), selain itu dapat juga digunakan untuk membantu siswa mengembangkan keterampilan berpikir, keterampilan menyelesaikan masalah, dan keterampilan intelektualnya (Sumartini, 2015, hlm. 2). Oleh karena itu, Model pembelajaran ini bisa digunakan untuk meningkatkan kemampuan representasi siswa melalui penyelesaian masalah, sehingga siswa dilibatkan secara aktif dalam proses maupun perolehan hasil penyelesaian masalah. Hal ini dapat diketahui dari salah satu fase yang terdapat pada fase membimbing penyelidikan individu dan kelompok. Siswa dituntut untuk dapat memahami, mengidentifikasi dan mengkontruk pengetahuaanya dalam menyelesaikan masalah pada LKPD. Fase ini dapat meningkatkan kemampuan representasi siswa dan ini sejalan dengan indikator representasi yaitu merubah suatu masalah matematika ke dalam bentuk gambar, diagram, grafik, dan tabel.

Salah satu materi yang diajarkan dalam pelajaran matematika adalah materi Persamaan Garis Lurus (PGL), karena masih banyak siswa yang tidak paham cara menyajikan PGL dalam berbagai bentuk reperesentasi. Banyak siswa yang tidak biasa mengerjakan soal cerita tentang PGL dengan baik karena mereka kurang paham dalam merepresentasikan soal terebut, sehingga dalam penyelesaian soalnya sering keliru. oleh karena itu, materi ini sesuai digunakan untuk melihat kemampuan representasi siswa.

Berdasarkan pada pertimbangan bahwa kemampuan representasi siswa yang masih rendah dan perangkat pembelajaran menggunakan model PBL yang mendukung siswa dalam meningkatkan kemampuan representasi, maka penelitian ini akan menjawab pertanyaan, Bagaimana peningkatan Kemampuan Representasi Matematis setelah di terapkan Model PBL pada Siswa SMP/MTs? dan Bagaimana Peningkatan Kemampuan Representasi Matematis Siswa SMP/MTs antara kelas yang dibelajarkan dengan Model PBL dengan Peningkatan Kemampuan Representasi Matematis Siswa yang dibelajarkan dengan Pembelajaran Konvensional?

\section{METODE}

Pendekatan yang dilakukan pada penelitian ini adalah pendekatan kuantitatif. Penelitian ini bertujuan untuk mengetahui kemampuan representasi matematis siswa setelah diterapkan Model PBL. Rancangan penelitian yang peneliti gunakan adalah penelitian quasi eksperimen dengan desain Control Group Pretest-Posttest Design. Subjek dalam penelitian ini adalah siswa kelas VIII-1 dan VIII-2 MTsN 3 Banda Aceh tahun ajaran 2018/2019 yang terdiri dari 55 orang siswa kemudian dikelompokan menjadi dua kelas, kelas VIII-1 sebagai kelas eksperimen dan kelas VIII2 sebagai kelas kontrol. Pengelompokan ini dilakukan untuk mengetahui capaian kemampuan representasi matematis siswa berdasarkan indikator kemampuan representasi matematis. 
Teknik pengumpulan data yang peneliti gunakan untuk terlaksananya penelitian dalam kegiatan belajar mengajar dengan menggunakan model pembelajaran PBL adalah tes dan observasi. Adapun instrumen yang digunakan dalam penelitian ini adalah Rencana Pelaksanaan Pembelajaran (RPP), Lembar Kerja Peserta Didik (LKPD), Lembar Evaluasi, dan Materi ajar, Lembar Soal Tes Kemampuan Representasi Matematis, dan lembar observasi guru.

Analisis data dalam penelitian ini terdiri dari tes awal dan tes akhir pada kelas kontrol dan eksperimen. Analisis tes awal dan tes akhir untuk menguji hipotesis rumusan pertama digunakan adalah uji Gain Score.. Adapun rumusan hipotesis nol $\left(\mathrm{H}_{0}\right)$ dan hipotesis alternatif $\left(\mathrm{H}_{1}\right)$ adalah sebagai berikut:

$H_{0}$ : Kemampuan Representasi matematis siswa tidak meningkat secara signifikan setelah dibelajarkan dengan model PBL pada siswa SMP/MTs.

$H_{1}$ : Kemampuan Representasi matematis siswa meningkat secara signifikan setelah dibelajarkan dengan model PBL pada siswa SMP/MTs.

Data tentang peningkatan kemampuan komunikasi matematis siswa dihitung dengan uji $\mathrm{N}$ Gain, dengan kriteria nilai gain yaitu:

Tabel 1. Kriteria N-Gain

\begin{tabular}{cc}
\hline Skor Gain & Interpretasi \\
\hline $\mathrm{g} \geq 0.7$ & Efektivitas tinggi \\
$0.3 \leq \mathrm{g}<0.7$ & Efektivitas sedang \\
$\mathrm{g}<0.3$ & Efektivitas rendah \\
\hline
\end{tabular}

Data tentang peningkatan kemampuan komunikasi matematis siswa dihitung dengan uji paired sample t-test,

Analisis tes awal dan tes akhir untuk menguji hipotesis rumusan kedua digunakan uji-t sample independent. Adapun rumusan hipotesis nol $(\mathrm{H} 0)$ dan hipotesis alternatif $(\mathrm{H} 1)$ adalah sebagai berikut:

$H_{0}$ : Peningkatan Kemampuan Representasi matematis siswa pada materi Fungsi yang dibelajarkan dengan model PBL pada siswa SMP/MTs sama dengan Peningkatan Kemampuan Representasi matematis siswa yang dibelajarkan dengan model Konvensional.

$H_{1}$ : Peningkatan Kemampuan Representasi matematis siswa pada materi Fungsi yang dibelajarkan dengan model PBL pada siswa SMP/MTs lebih baik dari Peningkatan

Kemampuan Representasi matematis siswa yang dibelajarkan dengan model Konvensional.

Pengujian hipotesis ini menggunakan statistik uji-t sampel independen. Pengujian hipotesis ini dilakukan pada taraf signifikansi $(\alpha)=0.05$ dan derajat kebebasan $(d k)=n_{1}+n_{2}-2$. Kriteria pengujiannya adalah jika $t_{\text {hitung }}>t_{\text {tabel }}$ maka $H_{0}$ ditolak dan terima $H_{0}$ jika $\mathrm{t}$ mempunyai harga-harga lainnya.

\section{HASIL DAN PEMBAHASAN}

\section{Hasil Penelitian}

Data nilai siswa sebelumnya diolah mnggnakan MSI kemudian dilanjutkan dengan distribusi nomal dan homogenitas. Keduanya las normal dan uji pretest normal dan homoen. Setelah normal emudian dilakukan uji t.

Hasil pengujian hipotesis pertama diperoleh, hasil uji N-Gain diperoleh sebanyak 3 siswa (11.11\%) kelas eksperimen memiliki tingkat N-Gain kategori "Tinggi", 20 siswa (74.07\%) yang memiliki tingkat N-Gain kategori "Sedang", dan 4 siswa (14.81\%) yang memiliki tingkat N-Gain 
kategori "Rendah" dan N-Gain Score, rata-rata kemampuan siswa kelas yang dibelajarkan model pembelajaran PBL adalah 0.43 yang memiliki rata-rata tingkat N-Gain "sedang".

Sedangkan rata-rata kemampuan siswa kelas yang dibelajarkan pembelajaran Konvensional adalah 0.29 yang memiliki rata-rata tingkat N-Gain"rendah". Berdasarkan pengujian hipoteis dapat disimpulan bahwa dengan menerapkan model pembelajaran $P B L$ dapat menigkatkan kemampuan representasi matematis siswa.

Model pembelajaran PBL dapat meningkatkan kemampuan representasi matematis siswa. Dimana nilai $t_{\text {hitung }}=7.00$ dan $t_{\text {tabel }=1,675}$ Jadi, Karena $t_{\text {hitung }}>t_{\text {tabel }}$ atau $7.00>1.675$, maka tolak $H_{0}$ sehingga diterima $H_{1}$

Sedangkan hasil pengujian hipotesis kedua, hasil rata-rata peningkatan kemampuan komunikasi matematis siswa kelas eksperimen adalah $\bar{x}=16,50$ dan kelas kontrol adalah $\bar{x}=15,11$ dengan simpangan baku kelas eksperimen $s_{1}=1,21$ dan kelas kontrol $s_{2}=1,66$ sesuai dengan hipotesis yang telah disebutkan pada rancangan penelitian dan perolehan data yang telah dianalisis maka diperoleh nilai $\mathrm{t}$ untuk kedua kelas yaitu thitung $=7.00$ dan ttabel 1.675. hasil ini menunjukkan thitung $>$ ttabel atau atau $7.00>1.675$. dapat disimpulkan bahwa Peningkatan Kemampuan representasi matematis siswa MTsN 3 Banda Aceh yang diterapkan model PBL lebih baik dari kemampuan representasi matematis siswa yang diterapkan dengan pembelajaran konvensional pada materi Persamaan Garis Lurus.

hasil deskripsi jawaban Pre-tes dan Post-test menunjukkan bahwa kemampuan representasi matematis siswa kelas eksperimen terhadap indikator kemampuan representasi matematis yaitu:

1. Menuliskan langkah-langkah penyelesaian masalah matematika dengan kata-kata yang telah dipelajari mengalami peningkatan dari yang sebelumnya $7.40 \%$ menjadi $66.66 \%$

2. Menyajikan data atau informasi dari suatu masalah ke representasi gambar, diagram, grafik atau tabel mengalami peningkatan dari yang sebelumnya $11.11 \%$ menjadi $57.40 \%$.

3. Menyelesaikan masalah yang melibatkan ekspresi matematis mengalami peningkatan dari yang sebelumnya $0 \%$ menjadi $51.85 \%$.

\section{Pembahasan}

Peneliti memberikan tes individual kepada seluruh siswa berupa pretest, lembar evaluasi dan postest yang memuat indikator kemampuan representasi matematis siswa. Untuk soal pretest dan postest, peneliti memberikan 2 soal yang memuat ketiga indikatornya, sedangkan untuk lembar evaluasi hanya diberikan 1 soal yang memuat indikator kemampuan representasi yang disesuaikan dengan indikator capaian pembelajaran. Rubrik yang digunakan untuk melakukan penilaian terhadap soal tes dan lembar evaluasi terdiri dari beberapa kriteria dengan menggunakan skala 1 , 2 , dan 3 .

Berikut uraian hasil jawaban pre-test dan post-test siswa A dan siswa B kelas eksperimen:

\section{- Siswa A}

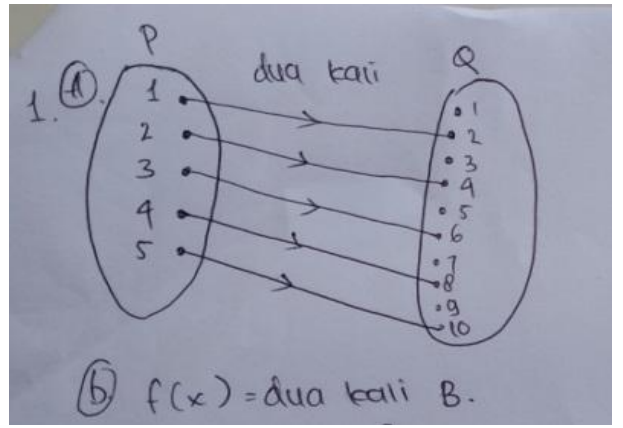

Gambar 1. a Jawaban Pretest Siswa Gambar 


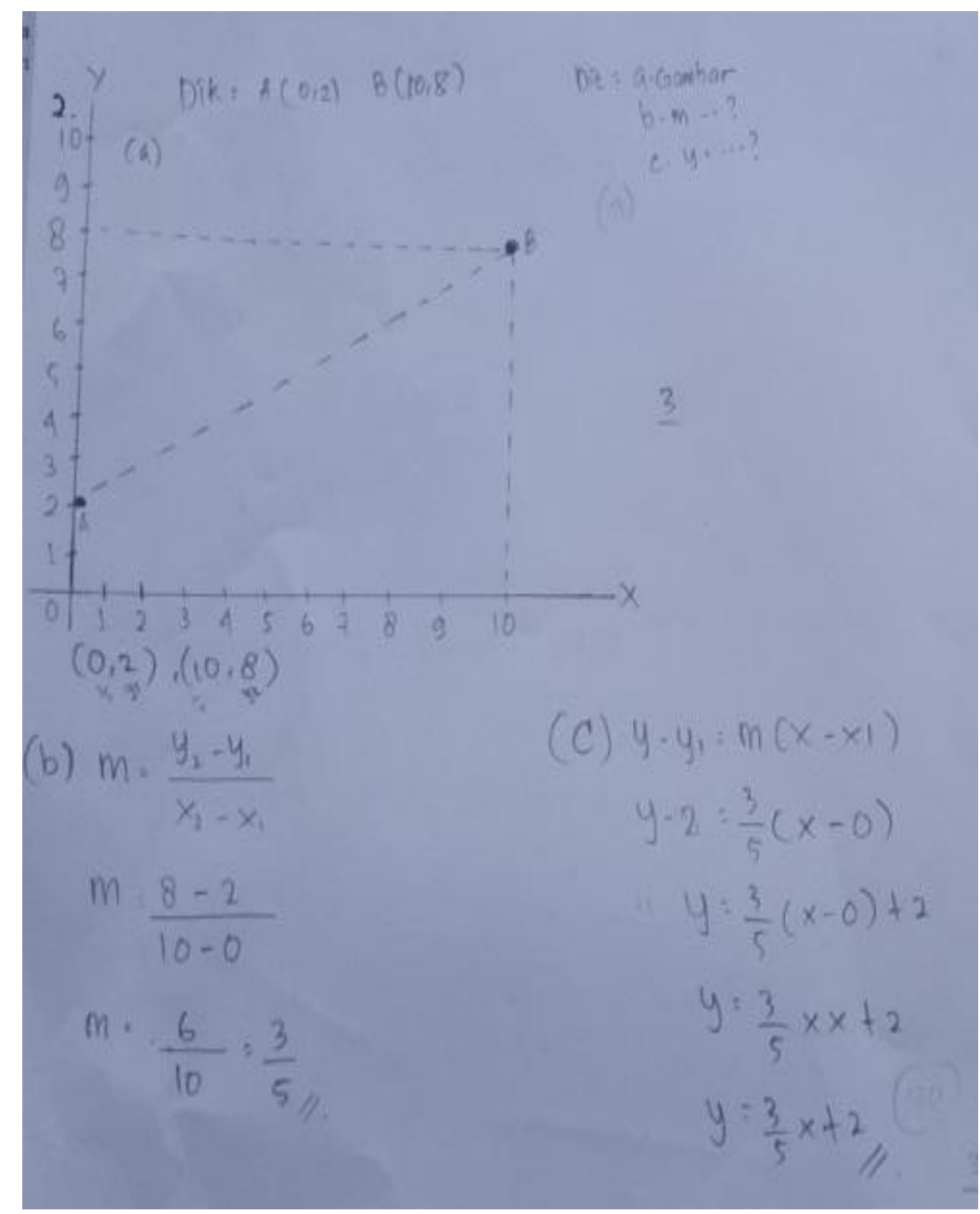

Gambar 1. b Jawaban Postest Siswa

Pada jawaban (Gambar 1.a) dapat dilihat bahwa Siswa A ketika pre-test dapat menghasilkan ide untuk soal fungsi dengan merepresentasikan soal tersebut ke dalam diagram panah dengan benar, tidak dapat merepresentasikan soal ke dalam kata-kata terlebih dahulu, dan perhitungan aljabar untuk menentukan rumus dari fungsi yang dibuatnya belum didapatkan, namun setelah diterapkan pembelajaran PBL, dilakukan pos-test, hasilnya dilihat pada Gambar 1.b terlihat bahwa siswa A mampu merepresentasikan soal kedalam kata-kata terlebih dahulu. Mengilustrasikan masalah pada soal ke representasi diagram cartesius, menggunakan rumus dengan tepat dan perhitungannya benar.

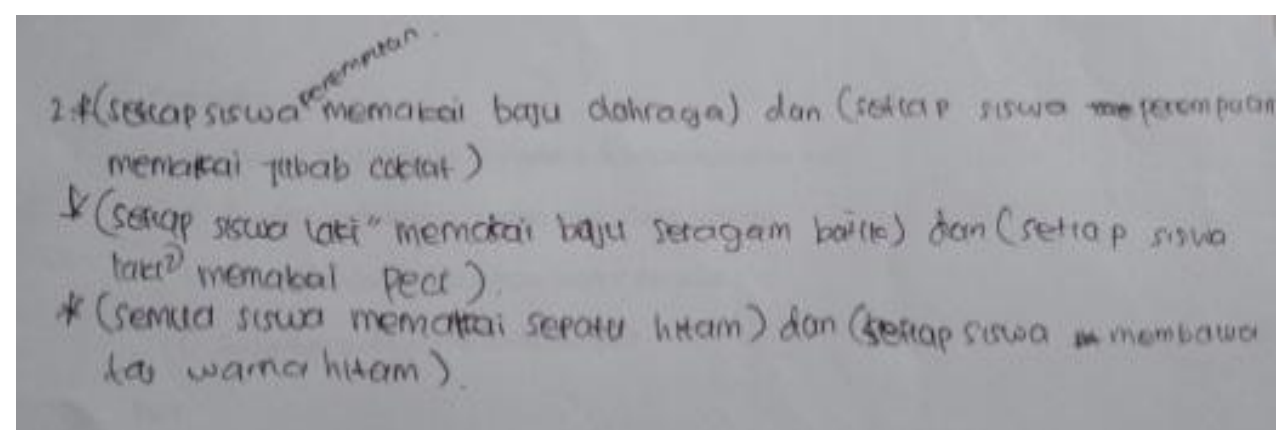

Gambar 2.a Jawaban Pretest Siswa 


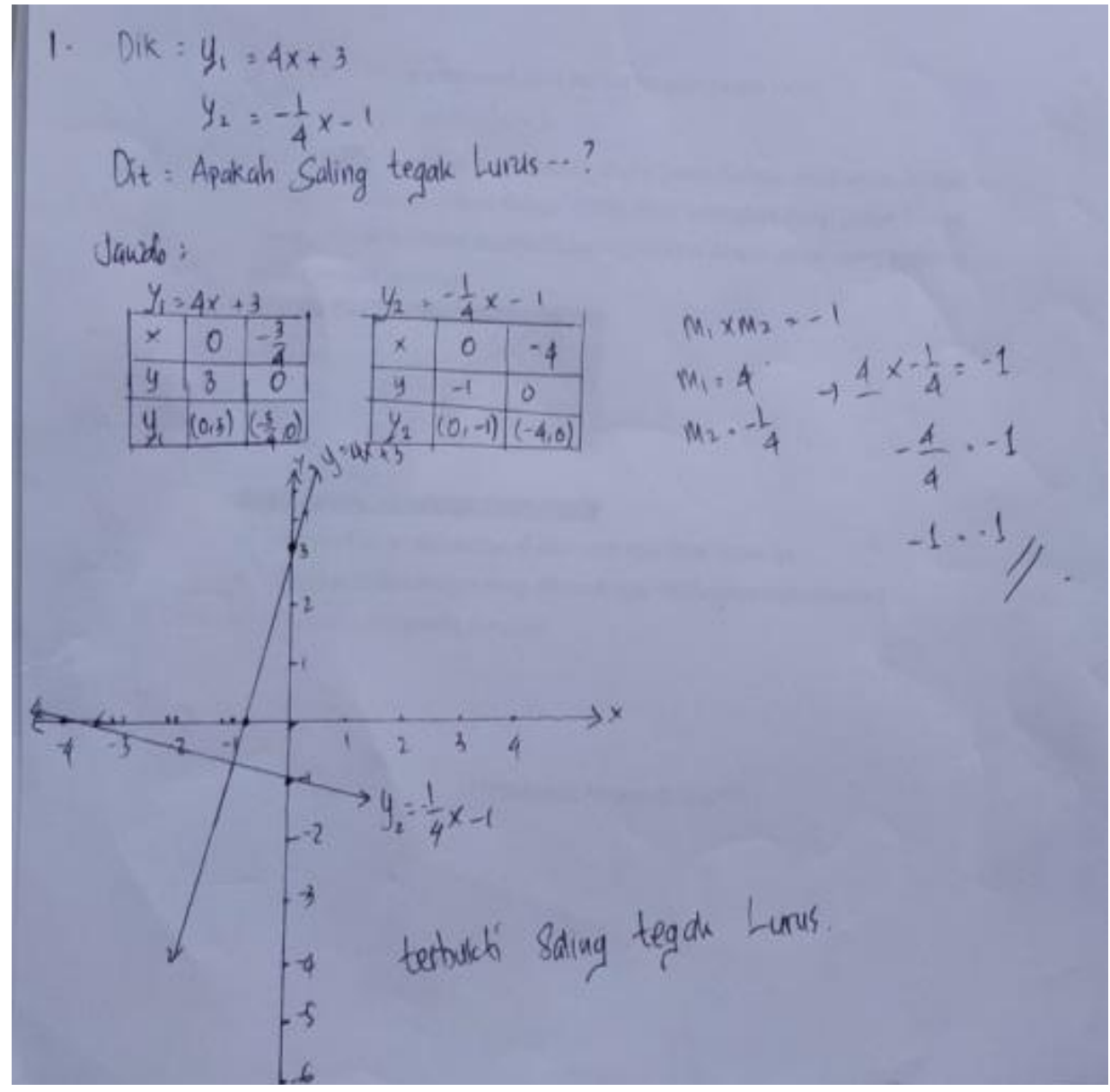

Gambar 2.b Jawaban Postest Siswa

Pada jawaban (Gambar 2.a) dapat dilihat bahwa Siswa A ketika pre-test menghasilkan ide untuk soal fungsi dengan merepresentasikan soal tersebut kedalam pasangan berurut namun belum tepat, tidak dapat merepresentasikan soal kedalam kata-kata terlebih dahulu, namun setelah diterapkan pembelajaran PBL, dilakukan pos-test, hasilnya dilihat pada Gambar 2.b bahwa siswa A mampu merepresentasikan soal kedalam kata-kata terlebih dahulu. Menjawab dengan cara yang berbeda dengan merepresentasikan ke diagram cartesius, menggunakan rumus dengan tepat dan perhitungannya benar.

Berdasarkan uraian di atas, setelah pembelajaran PBL dilaksanakan dapat diktahui bahwa kemampuan representasi matematis siswa A memenuhi tiga indikator yaitu menyelesaikan masalah yang melibatkan ekspresi matematis, mengilustrasikan masalah ke representasi diagram serta menuliskan langkah-langkah penyelesaian masalah matematika dengan kata-kata.

\section{- Siswa B}

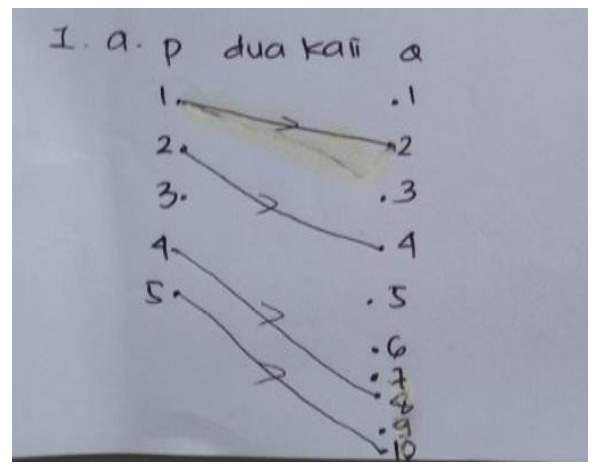

Gambar 3.a Jawaban Pretest Siswa 


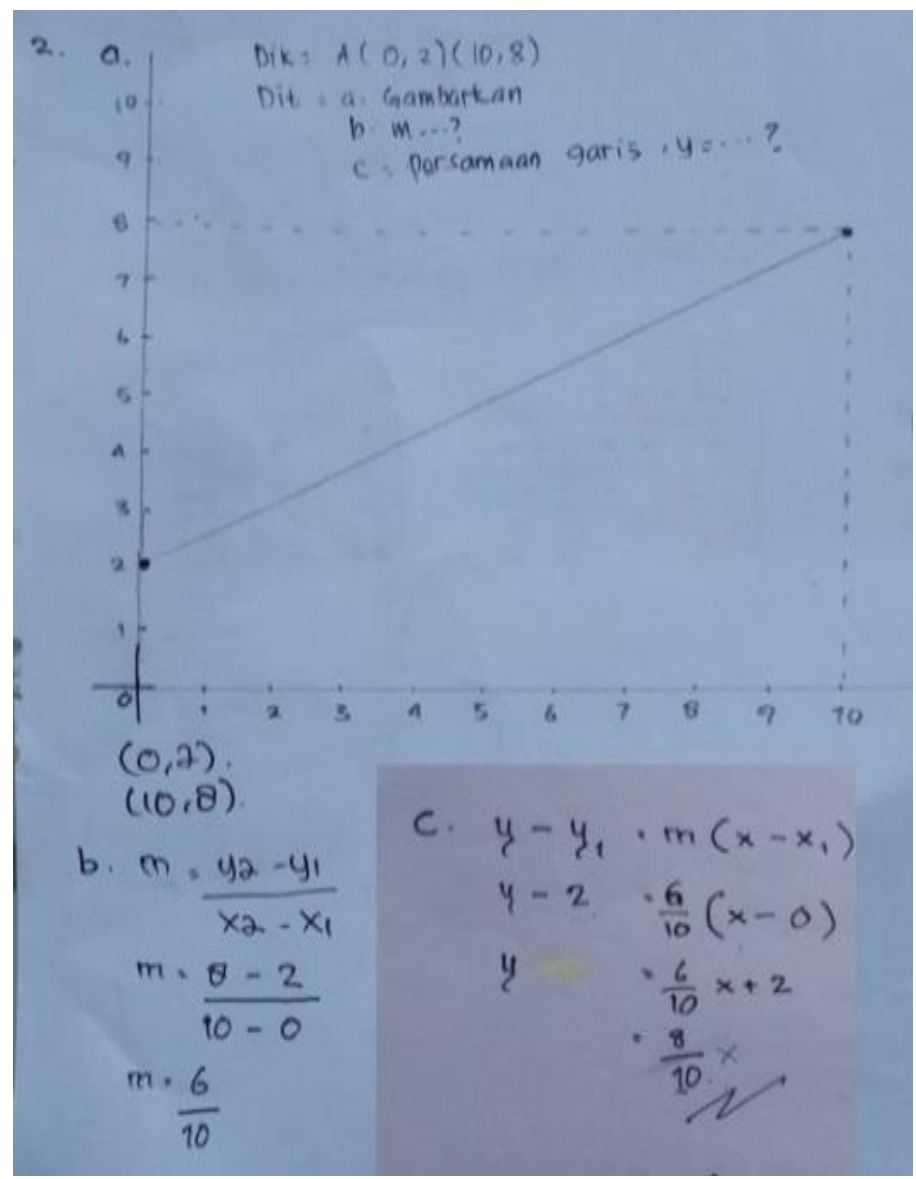

Gambar 3.b Jawaban Postest Siswa

Pada jawaban (Gambar 3.a) dapat dilihat bahwa Siswa B ketika pre-test menghasilkan ide untuk soal fungsi dengan merepresentasikan soal tersebut kedalam diagram panah namun belum tepat karna diagramnya tidak dibuat, tidak dapat merepresentasikan soal kedalam kata-kata terlebih dahulu, dan perhitungan aljabar untuk menentukan rumus dari fungsi yang dibuatnya belum didapatkan, namun setelah diterapkan pembelajaran PBL, dilakukan pos-test, hasilnya dilihat pada Gambar 3.b bahwa siswa B dapat merepresentasikan soal kedalam kata-kata terlebih dahulu. Mengilustrasikan masalah pada soal ke representasi diagram cartesius, menggunakan rumus dengan tepat dan perhitungannya mendekati benar.

\section{A:E Gendera Indonesia, Bendera Amerikat)

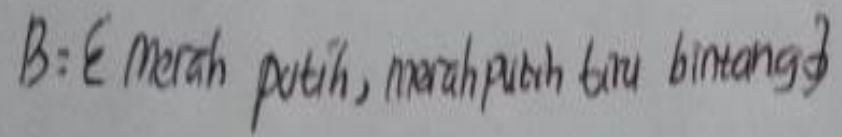

Gambar 4.a Jawaban Pretest Siswa 


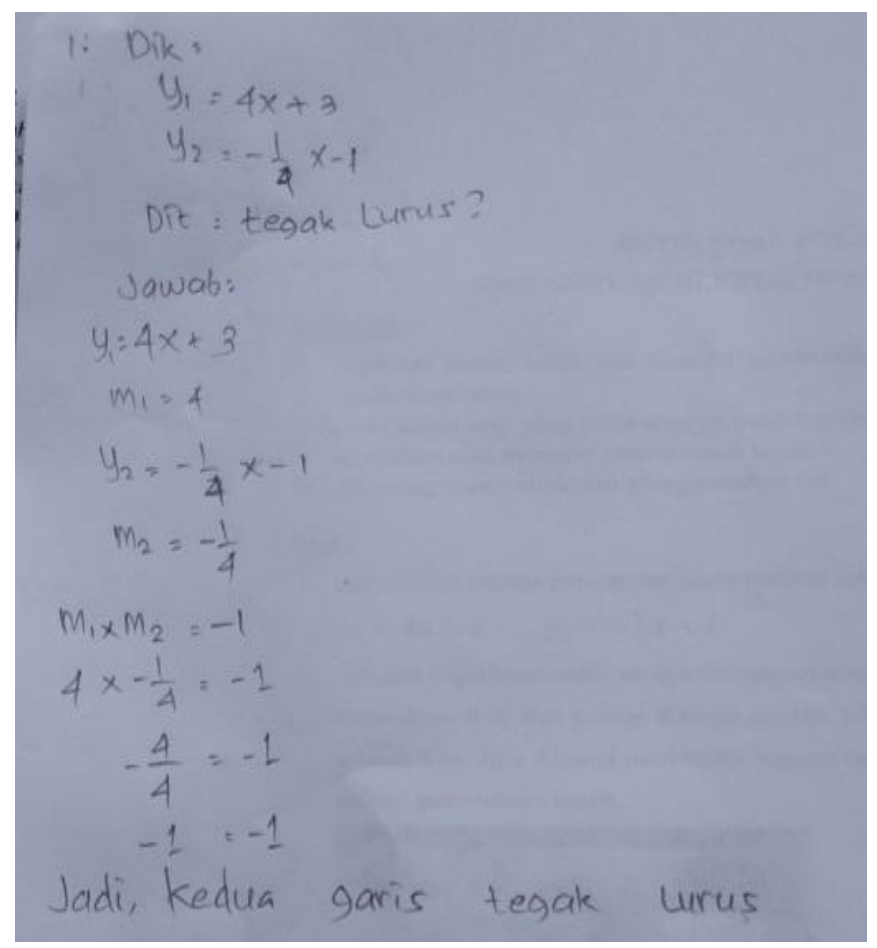

Gambar 4.b Jawaban Postest Siswa

Pada jawaban (Gambar 4.a) dapat dilihat bahwa Siswa B ketika pre-test dapat menghasilkan ide untuk soal fungsi dengan merepresentasikan soal kedalam kata-kata terlebih dahulu, tidak dapat mengilustrasikannya kedalam diagram ataupun pasangan berurutan, namun setelah diterapkan pembelajaran PBL, dilakukan pos-test, hasilnya dilihat pada Gambar 4.b bahwa siswa B dapat merepresentasikan soal kedalam kata-kata terlebih dahulu dan menggunakan rumus dengan tepat dan perhitungannya benar.

Berdasarkan uraian di atas, setelah pembelajaran PBL dilaksanakan dapat diktahui bahwa kemampuan representasi matematis siswa B memenuhi tiga indikator yaitu menyelesaikan masalah yang melibatkan ekspresi matematis, mengilustrasikan masalah ke representasi diagram serta menuliskan langkah-langkah penyelesaian masalah matematika dengan kata-kata, namun perhitungannya masih kurang tepat.

kemampuan representasi matematis siswa kelas eksperimen terhadap seluruh indikator kemampuan representasi matematis dalam kategori rendah mengalami penurunan dari yang sebelumnya $48.13 \%$ menjadi $12.96 \%$, sedangkan siswa yang berkategori sangat baik mengalami peningkatan dari yang sebelumnya $18.51 \%$ menjadi $58.63 \%$.

Adapun indikator yang peningkatannya paling sedikit adalah indikator visual yaitu indikator yang mencakup kemampuan mengambar atau melukis secara tepat dan benar. Hal ini terjadi dikarenakan siswa kurang mampu mengidentifikasi unsur-unsur yang saling berkaitan seperti menetukan titik perpotongan secara tepat dan benar sehingga penyelesaian yang dilakukan tidak saling terkait yang berakibat siswa tidak mampu menggambar atau melukis dengan tepat. Indikator simbolik juga mempengaruhi tahap visual, ketika kemampuan simbolik rendah akan berakibat kepada rendahnya pada kemampuan visual. Hal ini terjadi tahap visual membutuhkan informasi yang akurat pada indicator simbolik.

Berdasarkan hasil analisis kemampuan guru diperoleh gambaran bahwa pembelajaran dengan model PBL berperan baik dalam membinbing siswa yang mengalami kesulitan dalam pembelajaran matematika, terutama untuk mengatasi rendahnya kemampuan representasi matematis siswa. Adapun skor rata-rata yang diperoleh guru dalam mengelola pembelajaran untuk lima kali pertemuan dengan menerapkan model PBL adalah 4.82 dan masuk pada kategori sangat baik. 
Dalam hal ini, dapat dikatakan bahwa guru dapat melaksanakan pembelajaran dengan model PBL tanpa mengalami kesulitan dan kemampuan guru dalam mengelola pembelajaran dengan model PBL dikatakan efektif. Sehingga dapat diambil kesimpulan bahwa guru telah melaksanakan kegiatan pembelajaran sesuai dengan langkah-langkah model pembelajaran PBL pada materi Persamaan Garis Lurus.

Adapun temuan dalam penelitian ini adalah Siswa lebih aktif dalam proses pembelajaran, dengan pembelajaran yang selalu dimulai dengan permasalahan maka siswa lebih mudah dan terarah dalam memecahkan permasalan matematis. Penilaian yang diberikan guru mencakup seluruh indikator kemampuan reprsentasi, guru sudah mulai mencoba menggunakan perangkat pada materi lain dan lebih bersemangat dalam mengajar menggunakan perangkat tersebut dan mulai mencari video pembelajaran yang membuat siswa aktif. Tampak adanya perbedaan cara mengajar guru sebelum dan sesudah menggunakan perangkat model PBL.

\section{KESIMPULAN}

Berdasarkan hasil penelitian dan pembahasan tentang kemampuan representasi matematis siswa melalui model PBL, maka diperoleh kesimpulan bahwa siswa yang berkemampuan tinggi dan sedang memenuhi ketiga indikator kemampuan representasi matematis yaitu menuliskan langkahlangkah penyelesaian masalah matematika dengan kata-kata, menyajikan data atau informasi dari suatu masalah ke representasi gambar, diagram, grafik atau tabel, serta menyelesaikan masalah yang melibatkan ekspresi matematis. Siswa berkemampuan rendah memenuhi dua indikator kemampuan representasi matematis yaitu menuliskan langkah-langkah penyelesaian masalah matematika dengan kata-kata dan menyelesaikan masalah yang melibatkan ekspresi matematis. Disarankan kepada pihak lain untuk melakukan penelitian yang sama pada materi yang berbeda sebagai bahan perbandingan dengan hasil penelitian ini atau materi yang sama namun mendapatan nilai N-Gain dengan kategori "tinggi".

\section{PENGHARGAAN}

Terima kasih kepada seluruh pihak yang telah ikut serta membantu dan mengevaluasi jurnal ini. terima kasih kepada pembimbing, guru disekolah para dosen dan juga teman-teman semua. Semoga jurnal ini bermanfaat.

\section{DAFTAR PUSTAKA}

Bagus, C. (2018). Analisis Kemampuan Representasi Matematis Siswa Dalam Menyelesaikan Soal Lingkaran Pada Kelas VII-B Mts Assyafi'iyah Gondang. Suska Journal of Mathematics Education, 4(2), 115-124. https://doi.org/10.24014/sjme.v4i2.5234

Farhan, M., \& Retnawati, H. (2014). Keefektifan PBL dan IBL ditinjau dari Prestasi Belajar, Kemampuan Representasi Matematis, dan Motivasi Belajar. Jurnal Riset Pendidikan Matematika, 1(2), 227-240. https://doi.org/10.21831/jrpm.v1i2.2678

Hidayat, R., Roza, Y., \& Murni, A. (2019). Peran Penerapan Model Problem Based Learning (PBL) terhadap Kemampuan Literasi Matematis dan Kemandirian Belajar. JURING Journal for Research in Mathematics Learning), 1(3), 213-218. https://doi.org/10.24014/juring.v1i3.5359

National Council of Teachers of Mathematics. (2000). Principles and Standards for School Mathematics. Reston, Virginia: National Council of Teachers of Mathematics.

Nurjani -. (2016). Pengaruh Model Pembelajaran Kooperatif Tipe Think Pair Share (TPS) terhadap Kemampuan Representasi Matematis Siswa Kelas VIII MTs Thamrin Yahya Rambah Hilir. Jurnal Ilmiah Mahasiswa FKIP Prodi Matematika, 2(2). Diambil dari http://ejournal.upp.ac.id/index.php/mtkfkip/article/view/914 
Reski, R., Hutapea, N., \& Saragih, S. (2019). Peranan Model Problem Based Learning (PBL) Terhadap Kemampuan Pemecahan Masalah Matematis dan Kemandirian Belajar Siswa. JURING Journal for Research in Mathematics Learning), 2(1), 049-057. https://doi.org/10.24014/juring.v2i1.5360

Sabrina, F. (2015). Penerapan Model Problem Based Learning (PBL) untuk. Meningkatkan Kemampuan Representasi Matematis Siswa SMP. (Skripsi, Universitas Pendidikan Indonesia). Diambil dari http://repository.upi.edu/17580/

Sari, I. J., \& Sari, A. (2019). Pengaruh Penerapan Model Pembelajaran Think Pair Share terhadap Kemampuan Representasi Matematis ditinjau dari Kemampuan Awal Matematika Siswa. JURING Journal for Research in Mathematics Learning), 2(3), 191-196. https://doi.org/10.24014/juring.v2i3.7525

Sumartini, T. S. (2015). Peningkatan Kemampuan Penalaran Matematis Siswa Melalui Pembelajaran Berbasis Masalah. Mosharafa: Jumal Pendidikan Matematika, 4(1), 1-10.

Susilawati, S., Chandra, T. D., \& Abadyo, A. (2019). Kemampuan Representasi Matematis Siswa Kelas XI melalui Penerapan Model Problem Based Learning. Jurnal Pendidikan: Teori, Penelitian, Dan Pengembangan, 4(8). https://doi.org/10.17977/jptpp.v4i8.12402 